\title{
TECNOLOGIA SOCIAL EM BUSCA DO DESENVOLVIMENTO SUSTENTÁVEL DA AGRICULTURA FAMILIAR: UM ESTUDO DE CASO SOBRE AS CASAS DE SEMENTES COMUNITÁRIAS DO MUNICÍPIO DE CRATO
}

\author{
SOCIAL TECHNOLOGY AIMING FOR THE SUSTAINABLE DEVELOPMENT \\ OF FAMILY AGRICULTURE: A CASE STUDY ABOUT COMMUNITY SEED \\ HOUSES IN THE CITIE OF CRATO.
}

\author{
${ }^{1 *}$ Silvério de Paiva Freitas Júnior \\ 2 Tainara Gomes Martins Jácome \\ ${ }^{3}$ Ana Paula Candido Gabriel Berilli \\ ${ }^{4}$ Flávia Nicácio \\ ${ }^{5}$ Cícero Cordeiro Pinheiro \\ ${ }^{6}$ Maria das Dores Amaro dos Santos
}

\begin{abstract}
${ }^{1}$ Universidade Federal do Cariri E-mail: silverio.freitas@ufca.edu.br.
${ }^{2}$ Universidade Federal do Cariri E-mail: tainara.jacome@ufca.edu.br.

${ }^{3}$ Instituto Federal do Espírito Santo, Ifes campus Alegre. E-mail: ana.berilli@ifes.edu.br. ${ }^{4}$ Universidade Estadual do Norte Fluminense Darcy Ribeiro. E-mail: flaalegre@hotmail.com

${ }^{5}$ Universidade Federal do Cariri E-mail: cicero.cordeiro@aluno.ufca.edu.br.

${ }^{6}$ Universidade Federal do Cariri E-mail: dasdores708@gmail.com.

*Autor de correspondência
\end{abstract}

Artigo submetido em 23/11/2021, aceito em 02/12/2021 e publicado em 30/12/2021.

\begin{abstract}
Resumo: O cultivo das sementes crioulas simboliza a chave para os sistemas de base agroecológica, essas variedades apresentam defesas contra vulnerabilidades das lavouras, como a resistência a intempéries climáticas, pragas e doenças. Entretanto, nos últimos anos o cultivo dessas sementes vem diminuindo e uma das formas de conservar e resgatar essas variedades é através das Casas de Sementes Comunitárias, essas são estruturas conduzidas por organizações de base comunitária e constitui uma importante ferramenta para a chamada conservação in situ/on farm. Diante da importância dessa tecnologia social, a pesquisa teve por objetivo caracterizar as Casas de Sementes Comunitárias do município de Crato. A pesquisa documental, entrevistas e levantamento das coordenadas geográficas foram as técnicas de coleta de dados utilizadas para delinear a pesquisa. Foram identificadas sete Casas de Sementes em Crato. Durante o estudo observou-se que as Casas de Sementes contribuem para o desenvolvimento sustentável das comunidades as quais estão inseridas. Entretanto, a falta de incentivo e apoio, o desinteresse dos jovens e as condições climáticas são os principais motivos que influenciam a inativação de algumas das Casas de Sementes identificadas na pesquisa.
\end{abstract}

Palavras-chave: Sementes crioulas; Sustentabilidade; Agrobiodiversidade. 
Abstract: The cultivation of creole seeds symbolizes the key to the systems of agroecological base, these varieties present defenses against vulnerabilities of the crops, such as the resistance to climatic intemperism, plagues and diseases. However, in recent years the cultivation of these seeds has been decreasing, but one of the ways to conserve and recover these varieties is through community seed houses, these establishment are structures managed by community-based organizations and constitute an important tool for so-called conservation in situ/on farm. Knowing the importance of this social technology, the research aimed to characterize the community seed houses of the citie of Crato. The documentary research, interviews and survey of geographical coordinates were used as the techniques of data collection for this research. Three seed houses in Nova Olinda and seven in Crato were identified. During the study it was observed that the Seed Houses contribute to the sustainable development of the communities to which they are inserted. However, the lack of encouragement and support, youthful disinterest and climatic conditions are the main reasons that influence the inactivation of at seed houses identified in the research.

Keywords: Creole seeds; Sustainability; Agrobiodiversity.

\section{INTRODUÇÃO}

A agricultura familiar é aquela em que a família, ao mesmo tempo que é proprietária dos meios de produção, assume o trabalho no estabelecimento produtivo (WANDERLEY, 2001). Nesse modelo, em que a estrutura produtiva associa famíliaprodução-trabalho podemos destacar sua contribuição para a sustentabilidade, considerando as dimensões econômica, social e ambiental.

Para Lamarche (2007) “A agricultura familiar não é um elemento da diversidade, mas contém, nela mesma, toda a diversidade”. A essa fala pode-se atribuir, especialmente, a conservação da agrobiodiversidade, uma vez que a policultura é característica básica da agricultura camponesa e inclui roçados diversificados, cultivos de hortaliças e frutíferas. Além disso, a conservação das sementes é realizada pelos próprios agricultores em suas residências ou em Casas de Sementes.

Soma-se, também, a essas características os processos de experimentação e inovação conduzidos pelos agricultores familiares, bem como o intercâmbio de saberes agrícolas e sementes. Sabe-se que o processo de seleção, domesticação de plantas e de animais e o desenvolvimento de novas variedades é contínuo e para isso a agricultura é permanentemente reinventada e redescoberta pelos próprios agricultores, para atender a necessidades sociais, culturais e econômicas dinâmicas (SANTILLI, 2009).

Mudanças ocorridas na agricultura, sobretudo, a partir da revolução verde, têm levado à ocorrência de alguns problemas à sociedade, como: a perda da diversidade agrícola (erosão genética), a simplificação dos sistemas produtivos e o empobrecimento da agricultura familiar (BEVILAQUA et al., 2009; SANTILLI, 2012).

Diante desse contexto, alterações relacionadas ao uso de recursos genéticos na agricultura resultaram na marginalização das sementes crioulas ocasionando a extinção de muitas variedades e a redução da população de outras. Esse processo conhecido como erosão genética, além de resultar na desaparição física das variedades, também contribui para a perda dos conhecimentos culturais associados ao uso tradicional das espécies nativas e variedades locais (LONDRES, 2014; MACHADO, 2014).

A biodiversidade deve ser protegida para garantir os direitos das futuras gerações e frente aos prejuízos decorrentes da perda da 
diversidade agrícola, em várias partes do mundo, algumas estratégias vêm sendo defendidas e implementadas com o intuito de reprimir o processo de perda de recursos genéticos e dos conhecimentos dos agricultores familiares (BEVILAQUA et al., 2009; LONDRES, 2014).

Nesse sentido, a conservação ex situ e a conservação in situ/on farm são as duas principais estratégias (SANTILLI, 2009; PERTERSEN et al., 2013; LONDRES, 2014).

O método ex situ consiste na conservação fora do seu local de origem, já o método in situ/on farm é a manutenção dos recursos genéticos no seu habitat natural, por iniciativa das próprias comunidades rurais (SANTILLI, 2009).

O método ex situ, baseado na coleta de materiais do campo e no seu armazenamento em centros de pesquisa agrícola, bancos de germoplasma e em jardins botânicos, teve destaque nos últimos anos (LONDRES, 2014).

Na região do Cariri, a primeira Casa de Sementes foi construída na década de 1980. Após a articulação e construção de outras CSC, essas, também, passaram a integrar a RIS-CE. Entretanto com o passar dos anos, devido à falta de incentivos e de organização, muitos agricultores abandonaram a Rede. Hoje, poucos resistem e lutam para revitalizar o que denominaram de Rede de Intercâmbio de Sementes do Cariri-RIS (CARVALHO et al.,2014).

Dessa forma o objetivo desse trabalho foi de caracterizar as Casas de Sementes Comunitárias existentes no município de Crato - Ceará.

\section{REFERENCIAL TEÓRICO}

\subsection{HISTÓRIA DA AGRICULTURA}

Há muitos anos as plantas cultivadas hoje na agricultura existiam apenas como plantas selvagem, elas não precisavam ser plantadas para germinarem, nem de cuidados para se desenvolver e dar frutos. A sua utilização era somente através da coleta, e não do cultivo (MDA, 2006).

No entanto, há cerca de 10.000 a 12.000 anos, durante o período Neolítico, ocorreu a revolução agrícola neolítica, caracterizada pela transição da predação à agricultura. Durante esse processo o homem que havia desenvolvido utensílios aperfeiçoados e especializados para caçar, pescar e coletar passou a cultivar a terra e a criar animais. Esse processo que consiste na seleção, cultivo e criação de espécies vegetais e animais é chamado de domesticação. Assim, aos poucos, as sociedades de caçadores-coletores transformaram-se em sociedades de agricultores (MAZOYER e ROUDART, 2010).

A domesticação das plantas é um processo evolutivo, constituído de inúmeras mudanças genéticas e morfológicas, que podem ser percebidas a partir de modificações comportamentais humanas, as quais estão diretamente relacionadas com o desenvolvimento da agricultura de subsistência (cultivo), efetuada, primariamente, pelo grupo dos caçadores-coletores

(EMATERCE, 2009).

De acordo com Emperaire (2004) e Santilli (2009) a domesticação resulta na modificação do patrimônio genético da planta. Durante seus ciclos, a espécie perde algumas de suas características e outras, consideradas mais proveitosas para o homem, serão selecionadas. Quando a planta se adapta às novas condições criadas pelo homem, ela perde a capacidade de se desenvolver e se reproduzir em ambientes silvestres.

A domesticação de novas variedades de plantas cultivadas é considerada um processo contínuo (SANTILLI, 2009). É válido ressaltar que o processo de domesticação das plantas desempenhou um papel essencial para o desenvolvimento da 
agricultura. Ao longo do tempo a relação entre o homem $\mathrm{e}$ as plantas tornou-se simbiótica, resultando em uma interdependência recíproca (SANTILLI, 2009).

Santilli (2009) ressalta que a evolução da agricultura afetou o homem em tempos e lugares distintos, pois ela sofreu sucessivas transformações durante séculos. Mudanças ambientais, sociais, econômicas e culturais interferiram no desenvolvimento de novos sistemas agrícolas.

Entre os anos de 1920 e 1930 o russo, Nicolai Vavilov realizou uma expedição pelos continentes. O botânico estudou a diversidade genética das plantas cultivadas, bem como de seus parentes silvestres. Observou em suas pesquisas que durante a dispersão das espécies cultivadas a partir do seu local de origem, elas se dividiram em grupos morfológicos, ecológicos e geográficos. Percebeu, também, que em certas áreas do mundo, havia maior diversidade de plantas cultivadas do que outras, e concluiu que os centros de diversidade genética correspondem aos centros de origem das cultivadas (SERENO et al., 2008).

Frequentemente, uma espécie está relacionada com um centro, no entanto, às vezes ela pode ser encontrada em mais de um. Quando este fato ocorre, o local onde existe maior variabilidade é denominado de centro primário, e é considerado o local onde a espécie foi domesticada. Já o centro secundário se desenvolveu de tipos que migraram do centro primário (SERENO et al., 2008).

As espécies domesticadas se espalharam pelas diferentes regiões do mundo através dos centros de origem e do deslocamento das populações humanas em busca de novos espaços. Portanto, as plantas que hoje cultivamos resultaram do processo de domesticação e seleção que vem ocorrendo ao longo dos anos por agricultores, através da interação entre a natureza e o ser humano (MDA, 2006).

\subsection{AGROBIODIVERSIDADE E AS SEMENTES CRIOULAS}

A legislação brasileira conceitua cultivar local, tradicional ou crioula como a variedade desenvolvida, adaptada ou produzida por agricultores familiares, assentados da reforma agrária ou indígenas, com características fenotípicas bem determinadas e reconhecidas pelas respectivas comunidades (Lei $\mathrm{n}^{\circ}$ $10.711 / 2003 \S 2^{\circ}$ inciso XVI).

Considerando trabalhos sobre o tema, Londres (2014) destaca:

Fruto de cuidadoso trabalho de observação, seleção e cruzamentos, bem como de práticas tradicionais de trocas, essas sementes são altamente adaptadas às condições específicas das regiões. Materiais rústicos portadores de alta variabilidade genética, são capazes de garantir a produção em ambientes com pouca ou nenhuma utilização de fertilizantes solúveis e agrotóxicos, inclusive em regiões de solos classificados convencionalmente como de baixa fertilidade e clima seco e instável. Em permanente processo de coevolução com as comunidades agrícolas, essas sementes não somente adaptam-se às condições biofísicas locais, como também atendem a grande diversidade de usos, manejos e preferências culturais (LONDRES, 2014).

Em cada região, as sementes crioulas recebem variadas denominações, no estado do Piauí são chamadas de Sementes da Fartura; em Minas Gerais, Sementes da Gente; na Paraíba, Sementes da Paixão; em Alagoas e Goiás, Sementes da Resistência. Independentemente de como são conhecidas, elas expressam uma forte relação com a identidade cultural das comunidades rurais (PETERSEN et al., 2013).

Ao contrário das variedades desenvolvidas nos centros de melhoramento 
genético, as sementes crioulas contêm grande diversidade genética (LONDRES, 2014). Conforme Altieri (2003) as variedades crioulas, selecionadas pelos agricultores, são geneticamente mais heterogêneas do que as variedades comerciais e podem oferecer um amplo leque de defesas contra vulnerabilidades.

As sementes tradicionais simbolizam a chave para os sistemas de base agroecológica, de baixa utilização de insumos externos e capazes de garantir o sustento e a segurança alimentar das famílias (LONDRES, 2014). De acordo com Machado (2003) a soberania alimentar começa com a independência do agricultor em dispor ou de poder adquirir suas próprias sementes.

O termo híbrido pode ser definido como a primeira geração proveniente do cruzamento entre variedades de polinização aberta, linhagens endogâmicas ou outras populações geneticamente divergentes (ALLARD, 1971). Os híbridos podem ser simples, triplos ou duplos. Os híbridos simples são o resultado do cruzamento de duas linhagens puras e indicados para sistemas de produção que utilizam alta tecnologia. O híbrido triplo é o cruzamento entre uma linhagem pura e um híbrido simples é indicado para média à alta tecnologia, enquanto o híbrido duplo é o resultado do cruzamento entre dois híbridos simples, sendo indicado também para média tecnologia. A grande vantagem dos híbridos em relação a linhas puras é o vigor de híbrido ou heterose. A desvantagem de sua utilização é a impossibilidade de reutilização das sementes híbridas, sendo que o produtor tem que comprar novas sementes a cada nova safra (CONAB, 2014).

Já as sementes transgênicas contêm genes retirados de organismos de diferentes espécies, que são inseridos diretamente em seus próprios materiais genéticos, com a finalidade de gerar plantas com específicas qualidades desejadas (LACEY, 2000). Uma das desvantagens na utilização das sementes transgênicas é que o produtor deve pagar royalties pelas sementes patenteadas, colocando em risco a segurança alimentar e à biodiversidade (GREENPEACE).

Frequentemente, as sementes comerciais, quando cultivadas por agricultores familiares, desempenham baixo desempenho. Possivelmente, este fato acorre pela não aquisição do "pacote tecnológico completo” recomendado para o cultivo, como: utilização de adubos sintéticos, correção do solo, irrigação e aplicação de agrotóxicos (ALTIERI, 2002; LONDRES, 2014).

Retomando às sementes tradicionais, Londres (2014) ressalta uma outra caraterística das variedades crioulas além da diversidade genética "é o fato de que elas não são estáticas - ao contrário, encontram-se em permanente processo evolutivo e de adaptação às condições ambientais e sistemas de cultivo. E não só: sua evolução é também influenciada pelas práticas sociais de troca e intercâmbio de material genético próprias das comunidades rurais de todo o planeta”.

A diversidade interespecífica, ou seja, dentro de uma mesma espécie, é uma característica exclusiva das sementes tradicionais. E essa heterogeneidade genética compõe um dos elementos fundamentais da agrobiodiversidade; incluindo a diversidade de espécies, a diversidade genética dentro das espécies e a diversidade de ecossistemas agrícolas e cultivados (SANTILLI, 2009; LONDRES, 2014).

Petersen et al. (2013) também destaca a importância das sementes para a agrobiodiversidade:

As sementes das espécies cultivadas são portadoras de mensagens genéticas e de mensagens culturais, além da pressão de seleção natural a que estão sujeitas todas as formas de vida, as espécies agrícolas foram historicamente submetidas a 
processos de domesticação, ou seja, à seleção cultural, o resultado dessas dinâmicas coevolutivas entre natureza e cultura foi a ampla diversificação biológica das espécies cultivadas, que hoje constitui um patrimônio genéticocultural reconhecido como bem comum da humanidade: a agrobiodiversidade (PETERSEN et al., 2013).

Conforme Santilli (2009) o termo agrobiodiversidade surgiu a quinze anos, em um contexto interdisciplinar que envolve diversas áreas do conhecimento, como: Agronomia, Antropologia, Ecologia, Botânica, Genética, Biologia etc. De acordo com a autora a agrobiodiversidade resulta da intervenção do homem sobre os ecossistemas. O conhecimento, a cultura, as práticas e inovações agrícolas, desenvolvidos e compartilhados pelos agricultores, são componentes-chave da agrobiodiversidade.

O conceito de
'agrobiodiversidade' reflete as
dinâmicas e complexas relações
entre as sociedades humanas, as
plantas cultivadas e os ambientes
em que convivem, repercutindo
sobre as políticas de conservação
dos ecossistemas cultivados, de
promoção da segurança alimentar
e nutricional das populações
humanas, de inclusão social e de
desenvolvimento rural sustentável
(SANTILLI, 2012).

\subsection{CONTRIBUIÇÕES}

DAS TECNOLOGIAS SOCIAIS PARA O DESENVOLVIMENTO SUSTENTÁVEL

Tecnologia social consiste em um conjunto de técnicas, metodologias transformadoras, desenvolvidas e/ou aplicadas na interação com a população e apropriadas por ela, que representam soluções para inclusão social e melhoria das condições de vida (ITS, 2007).

Para Dagnino (2014) as Tecnologias Sociais são organizações em que a propriedade dos meios de produção é coletiva, os trabalhadores realizam atividades econômicas de modo auto gestionário e a gestão e alocação dos resultados é decidida de forma participativa e democrática.

No Brasil, as Tecnologias Sociais vêm sendo discutida com frequência por diversos atores sociais, como organizações da sociedade civil, universidades, integrantes do governo, trabalhadores e outros, com o intuito de constituir respostas para o atendimento às demandas sociais (FERNANDES e MACIEL, 2010).

Conforme Fernandes e Maciel (2010) as Tecnologias Sociais são experiências constituídas por meio das iniciativas comunitárias locais, pelo saber popular em articulação com os saberes acadêmicos, por processos participativos e democráticos, portanto, o conhecimento é colocado a serviço do desenvolvimento social, e a tecnologia é uma mediação para a garantia dos direitos sociais.

Para Novaes e Dias (2009) as Tecnologias Sociais devem reunir as seguintes características:

1) ser adaptada a pequenos produtores e consumidores de baixo poder econômico;

2) não promover o tipo de controle capitalista, segmentar, hierarquizar e dominar os trabalhadores;

3) ser orientada para a satisfação das necessidades humanas;

4) incentivar o potencial e a criatividade do produtor direto e dos usuários;

5) ser capaz de viabilizar economicamente empreendimento como cooperativas populares, assentamentos de reforma agrária, a agricultura familiar e pequenas empresas.

A participação da sociedade local é sugerida como forma de garantir a efetividade da solução tecnológica, uma vez 
que a situação problema faz parte do cotidiano da população. As diferentes formas de saberes, da comunidade local, proporcionam a capacidade de esta participar do processo de pesquisa e desenvolvimento da tecnologia. Nesse contexto, a interação entre o homem e a tecnologia permite expressar ações que valorizem uma sociedade mais justa, inclusiva e sustentável (JESUS e COSTA, 2013).

As tecnologias sociais não enfatizam a ruptura entre o conhecimento popular e o conhecimento científico, pelo contrário, se destacam pela integração e são fontes de interação entre os saberes (ITS, 2007).

Os principais demandantes das tecnologias sociais são os empreendimentos solidários, quais sejam, cooperativas, associações, redes de solidariedade e outros (Reis 2012). Com a possibilidade de serem replicadas e compartilhadas, essas tecnologias procuram soluções para as demandas sociais relacionadas a água, alimentação, educação, energia, meio ambiente, saúde (ASA, 2016).

No Brasil é possível identificar uma ampla e diversificada produção de tecnologias sociais, dentre as quais tem destaque as que se desenvolvem na área da agricultura familiar (ITS, 2007). No semiárido brasileiro, por exemplo, tem ênfase as tecnologias direcionadas para os recursos hídricos, como: cisternas, barragens subterrâneas, tanque de pedra, barreiro trincheira, e bomba d'agua popular, além dessas, as mandalas, o viveiro de mudas, as feiras agroecológicas e as casas de sementes comunitárias vêm contribuindo para as demandas das populações locais.

Os avanços das tecnologias sociais na área da agricultura familiar adquirem uma dimensão que pode ser qualificada como estratégica, pelo seu potencial em relação ao desenvolvimento (ITS, 2007). Contribuindo para essa afirmação é valido expor o conceito de agricultura sustentável, em que esta é alcançada, muitas vezes, através da implantação de metodologias sociais.

Enfatizando para a tecnologia social que foi objeto de estudo dessa dissertação, Assunção e Severino (2015) conceituam Casas de Sementes Comunitárias (CSC) como aquelas que visam promover a sustentabilidade da agricultura familiar através do fortalecimento do intercâmbio de variedades tradicionais e as respectivas informações sobre o seu cultivo e uso, entre as famílias de agricultores.

Considerando trabalhos sobre o tema, Reis (2012) relata que a formação das Casas de Sementes Comunitárias constitui uma das estratégias dos agricultores familiares em estocar sementes, com a finalidade de garantir a quantidade necessária para a realização do plantio na época certa. Bem como sugerem a segurança para eventuais situações em que, por motivos climáticos ou econômicos, os agricultores não consigam produzir suas sementes.

O funcionamento dessas Casas é baseado no sistema de empréstimo e devolução. O agricultor associado a CSC toma emprestado determinada quantidade de sementes para a realização do plantio e após a colheita ele devolve à Casa a quantidade que tomou emprestada acrescido de um percentual. Este sistema permite aos agricultores que produzam e melhorem suas próprias sementes sob a gestão coletiva dos produtores familiares de comunidades rurais (QUEIROGA et al., 2011).

As CSCs, portanto, são ferramentas que possibilitam o fortalecimento da organização dos grupos, colaboram para a segurança alimentar e autonomia dos agricultores, bem como contribuem para a conservação das variedades tradicionais contribuindo, assim, para o desenvolvimento rural sustentável (LIMA e SAMPAIO [S.n.t]). 


\section{MATERIAL E MÉTODOS}

\subsection{LÓCUS DO ESTUDO}

Crato é um município que apresenta êxito na preservação da agrobiodiversidade pelos seus agricultores familiares, através das Casas de Sementes, dado este que eleva a importância de um estudo sobre esta Tecnologia Social. Este município está localizado no Sul do Estado do Ceará e faz parte da Região Metropolitana do Cariri. O período chuvoso nessa região ocorre entre janeiro e maio, e as temperaturas médias variam entre $24^{\circ}$ e $26^{\circ}$ (IPECE, 2015).

A cidade de Crato, em linha reta, é distante de Fortaleza $400 \mathrm{~km}$. Tem como municípios limítrofes: Caririaçu, Farias Brito, Barbalha, Juazeiro do Norte, Nova Olinda, Santana do Cariri e o Estado do Pernambuco. A população residente no município, em 2010, era 121. 428, sendo que 20. 512 habitavam a zona rural e 100 . 916 a zona urbana.

Quanto a divisão territorial, nove distritos compõe o município de Crato, são eles: Baixio das Palmeiras, Belmonte, Campo Alegre, Dom Quintino, Monte Alverne, Bela Vista, Ponta da Serra, Santa Fé e Santa Rosa (IPECE, 2015).

\subsection{NATUREZA DA PESQUISA}

Para a realização do estudo, técnicas de natureza qualitativa foram adotadas, como a descritiva e o Estudo de Caso. De acordo com Appolinário (2006) “a pesquisa descritiva busca apresentar uma realidade, sem nela interferir”.

E o Estudo de Caso é um método de pesquisa com mais profundidade de determinado caso. No entanto, o estudo é limitado, pois se restringe ao caso que estuda, ou seja, não podendo ser generalizado. $\mathrm{O}$ método reúne o maior número de informações detalhadas, utilizando diferentes técnicas para a coleta de dados, visando apreender uma determinada situação e descrever a complexidade de um fato (MARCONI E LAKATOS, 2007).

\begin{tabular}{|l|c|c|}
\hline $\begin{array}{l}\text { Casa de Semente } \\
\text { Comunitária } \\
\text { (Crato-CE) }\end{array}$ & \multicolumn{2}{|c|}{$\begin{array}{c}\text { Coordenadas } \\
\text { geográficas }\end{array}$} \\
\hline $\begin{array}{l}\text { Assentamento 10 } \\
\text { de Abril }\end{array}$ & $442206 \mathrm{E}$ & $9215323 \mathrm{~N}$ \\
\hline $\begin{array}{l}\text { Baixio das } \\
\text { Palmeiras }\end{array}$ & $457882 \mathrm{E}$ & $9194924 \mathrm{~N}$ \\
\hline Chico de Avelina & $454674 \mathrm{E}$ & $9195112 \mathrm{~N}$ \\
\hline Jenipapo & $456947 \mathrm{E}$ & $9209716 \mathrm{~N}$ \\
\hline Padre Cicero & $455142 \mathrm{E}$ & $9208705 \mathrm{~N}$ \\
\hline Santa Inês dos & $444441 \mathrm{E}$ & $9217818 \mathrm{~N}$ \\
\hline $\begin{array}{l}\text { Senhor } \\
\text { Exércitos }\end{array}$ & & \\
\hline 3.3. SU231 E & $9201579 \mathrm{~N}$ \\
\hline
\end{tabular}

3.3. SUJEITOS DA PESQUISA

A pesquisa foi realizada com os sete representantes das Casas de Sementes, ativas e inativas identificadas nas Comunidades rurais do município de Crato. Além desses, participaram também do estudo, representantes da ONG Cáritas Diocesana de Crato e Iguatu.

\subsection{COLETA E ANÁLISE DOS DADOS}

A pesquisa documental, entrevistas e levantamento das coordenadas geográficas foram as técnicas de coleta de dados utilizadas para delinear a pesquisa.

Através da pesquisa documental foi identificado $\mathrm{o}$ Projeto de indicação $\mathrm{n}^{\circ}$ 160/15 que dispõe sobre a Política Estadual de incentivo à formação dos Bancos Comunitários de Sementes e Mudas.

Foi realizado um levantamento prévio sobre as comunidades que apresentam Casas de Sementes, tanto ativa como inativa, no município de estudo. Contribuíram para esse levantamento preliminar, o Sindicato dos Trabalhadores Rurais de Crato, o Núcleo de Estudo em Fitotecnia e Melhoramento de Plantas (NEFIMP) da Universidade Federal do Cariri e as organizações não 
governamentais: Cáritas Diocesana de Crato e a Associação Cristã de Base.

Após o levantamento das Casas de Sementes, foram agendadas visitas com os representantes de cada Comunidade que apresentava a Tecnologia Social. Essas visitas ocorreram entre os meses de maio e agosto de 2016.

No início de cada entrevista com os representantes das Casas de Sementes foram apresentados dois termos, o Termo de Consentimento Livre e Esclarecido e o Termo de Autorização do uso da Imagem e do Depoimento, os quais esclareciam aos participantes o objetivo da pesquisa, a forma de coleta de dados, e a necessidade do uso da imagem e depoimento dos envolvidos no estudo.

Para a entrevista foi utilizado um formulário contendo indagações a respeito da Tecnologia Social estudada. Posteriormente ao diálogo, os representantes apresentavam o espaço físico das Casas de Sementes, e nesse mesmo momento também eram coletadas as coordenadas geográficas do local.

É válido lembrar que todas as informações sobre as Casas de Sementes visitadas foram disponibilizadas pelos seus respectivos representantes e estão descritas ao longo do trabalho. Ressalta-se, também, que esta pesquisa foi aprovada pelo Comitê de Ética em Pesquisa com Seres Humanos sob o $\mathrm{n}^{\circ}$ CAAE 56803516.8.0000.5055.

Para a análise dos dados observouse a relação entre as Casas de Sementes e quatro dimensões da sustentabilidade propostas por Sachs (2009), a ambiental, a social, a cultural e a econômica. Estas relações foram interpretadas através da técnica análise do conteúdo. De acordo com Bardin (1977) a análise de conteúdo é um conjunto de técnicas de análise das comunicações, que utiliza procedimentos sistemáticos e objetivos de descrição do conteúdo das mensagens.

\section{RESULTADOS E DISCUSSÃO}

\begin{tabular}{|l|c|c|}
\hline $\begin{array}{l}\text { Casa de Semente } \\
\text { Comunitária } \\
\text { (Crato-CE) }\end{array}$ & \multicolumn{2}{|c|}{$\begin{array}{c}\text { Coordenadas } \\
\text { geográficas }\end{array}$} \\
\hline $\begin{array}{l}\text { Assentamento 10 } \\
\text { de Abril }\end{array}$ & $442206 \mathrm{E}$ & $9215323 \mathrm{~N}$ \\
\hline $\begin{array}{l}\text { Baixio das } \\
\text { Palmeiras }\end{array}$ & $457882 \mathrm{E}$ & $9194924 \mathrm{~N}$ \\
\hline Chico de Avelina & $454674 \mathrm{E}$ & $9195112 \mathrm{~N}$ \\
\hline Jenipapo & $456947 \mathrm{E}$ & $9209716 \mathrm{~N}$ \\
\hline Padre Cicero & $455142 \mathrm{E}$ & $9208705 \mathrm{~N}$ \\
\hline Santa Inês dos & $444441 \mathrm{E}$ & $9217818 \mathrm{~N}$ \\
\hline $\begin{array}{l}\text { Senhor } \\
\text { Exércitos }\end{array}$ & $452391 \mathrm{E}$ & $9201579 \mathrm{~N}$ \\
\hline
\end{tabular}

4.1. IDENTIFICAÇÃO DAS CASAS DE SEMENTES COMUNITÁRIAS NO MUNICÍPIO DE CRATO.

Foram logradas sete Casas de Sementes Comunitárias na cidade de Crato (quadro 1).

Foram identificadas sete Casas de Sementes (três ativas e quatro inativas), nos distritos: Baixio das Palmeiras, Ponta da Serra, Monte Alverne, Bela Vista e no bairro Batateiras. A visitação ocorreu entre os dias 30/05/2016 e 12/08/2016.

Quadro 1: Coordenadas geográficas das respectivas casas de sementes comunitárias identificadas na pesquisa

Fonte: elaborado pelos autores.

\subsection{CASA DE SEMENTES BAIXIO DAS PALMEIRAS}

Intitulada com o nome do distrito em que está inserida, a Casa de Sementes Baixio das Palmeiras está localizada em uma das Comunidades que formam o distrito, a Comunidade Chapada do Baixio.

A visita a esta localidade ocorreu no dia 30/05/2016, e o representante da Casa de Sementes foi o agricultor José Cicero Braz, "Zé de Teta" como é chamado. A conversa teve início na residência do senhor José e na ocasião também estava presente o senhor Didi, agricultor e colaborador da referida Tecnologia Social. 
De acordo com o representante a Comunidade Chapada do Baixio tem aproximadamente 67 famílias. Destas, cerca de 26 tem como fonte de renda a agricultura familiar, os demais são aposentados ou assalariados que trabalham em empresas privadas.

A Casa de Sementes Baixio das Palmeiras foi criada em 2011 a partir do Projeto Solari. Para a construção da Casa os materiais necessários foram disponibilizados pelo projeto, e os próprios agricultores da localidade foram os responsáveis por construí-la. O senhor José relatou que foram necessários vários mutirões para erguer toda a estrutura, afirmou também que no início várias pessoas ajudaram, no entanto, no decorrer da construção poucos permaneceram na obra.

Durante o diálogo o agricultor fez uma observação relevante, pois até a data da realização dessa visita a estrutura da Casa de Sementes estava sendo utilizada como residência de uma família. Entretanto, a decisão de ceder a estrutura temporariamente partiu dos próprios associados, já que o casal estava sem lugar para residir enquanto constrói a sua residência na Comunidade.

Por esse motivo as atividades que habitualmente aconteciam na estrutura da CSC foram transferidas para a sede da Associação da Comunidade, bem como o estoque de sementes. Contudo, o agricultor afirmou que em breve devem retornar para a estrutura da Casa de Sementes já que a construção da residência do casal está quase finalizada.

Casa de Sementes: ser agricultor, ser defensor da semente natural e multiplicá-la, comparecer às reuniões, preencher uma ficha cadastral e se comprometer a devolver o dobro do empréstimo.

Atualmente a Casa conta com 25 associados, entretanto, apenas doze sócios dez homens e duas mulheres - frequentam as reuniões com regularidade. Os encontros são relatados em ata e acontecem mensalmente, no terceiro domingo, juntamente com a reunião da Associação, na sede desta.

Apesar da Casa de Sementes ainda não apresentar estatuto, o representante explica que algumas regras foram discutidas em reunião e registradas em ata. Como por exemplo, a norma de devolução do empréstimo, em que a quantidade emprestada deve ser devolvida com acréscimo de $100 \%$.

Em referência às sementes que compõe o estoque, estas foram obtidas através dos próprios agricultores da comunidade, e através de um intercâmbio que ocorreu em Maceió, no II Encontro Nacional de Sementes Crioulas. O representante afirma que apesar de não ter sementes em quantidade, existem diversas variedades de uma mesma cultura, garantindo, portando, a diversidade agrícola. As sementes disponíveis são de feijão, fava, milho, andu, amendoim, girassol, melancia, jerimum, gergelim.

$\mathrm{O}$ agricultor justifica que atualmente as sementes disponíveis não são suficientes para garantir a quantidade necessária para o plantio em cada safra pois a Casa foi criada recentemente e uma parte das sementes foi doada, além disso o fator principal foi a falta de chuva que interferiu no desenvolvimento das plantas nos últimos anos, contribuindo para a perda da produção.

Entre as medidas encontradas pelos agricultores para aumentar ou pelo menos manter o estoque das sementes na Casa é através do roçado comunitário, este fica ao lado da estrutura da Tecnologia Social. Esta forma de trabalho coletivo foi implantada pelos associados em 2015, em que são semeadas diversas culturas. Além da roça coletiva os agricultores plantam em seus quintais e tem o costume de guardar sementes em suas residências.

Quanto a realização de oficinas a respeito da coleta e armazenamento de sementes o representante afirma que não foi 
realizada nenhuma orientação nesse sentido aos membros da Casa. Ele ressalta ainda, que os agricultores demostram interesse em aprender novas técnicas, inclusive orientações com manejo de sementes nativas.

Assim como na maioria das Casas visitadas, as garrafas PET, também foram adotadas para o armazenamento das sementes. De acordo com o representante os agricultores preferem esse material pois acham ele mais seguro.

Durante o diálogo o Seu Zé relata sobre a gestão da referida Tecnologia Social, em que é o presidente da Associação que indica o responsável pela Casa de Sementes. Ao todo são 12 membros responsáveis pela gestão da Casa, dispostos nos cargos de presidente e vice, secretário e suplente, tesoureiro e suplente e três conselheiros fiscais e seus respectivos suplentes. O cargo de Presidente é ocupado pelo senhor José desde a fundação da Casa de Sementes, "por livre e espontânea pressão” brinca ele.

Atualmente a Casa de Sementes Baixio das Palmeiras não está sendo acompanhada por nenhum projeto, relata o representante, que também ressalta as dificuldades enfrentadas pelos membros da Casa durante as realizações de suas atividades. Entre as dificuldades, ele destacou as limitações em reintroduzir no cultivo sementes que há muitos anos não é cultivada na Comunidade; o desinteresse dos jovens e pouca mão de obra, bem como a falta de incentivo e apoio

\subsection{CASA DE SEMENTES SENHOR DOS EXÉRCITOS}

Fundada em 18 de julho de 1998 a Casa de Sementes Senhor dos Exércitos é um dos principais locais de proteção e conservação da agrobiodiversidade da região do Cariri, esta Tecnologia localiza-se no bairro Batateiras na cidade de Crato, e tem como principal gestor o agricultor Juvenal Januário Matos de 79 anos.
Seu Juvenal e Dona Durçulina, sua esposa, moram na comunidade Batateira desde a década de 1960, na época a localidade era conhecida como sítio Bom fim. Porém com o passar dos anos o bairro batateiras cresceu e avançou chegando até o sítio Bom fim.

Durante a visita do dia 27 o agricultor que já trabalha no campo desde sua infância contou um pouco sobre a história da Casa de Sementes Senhor dos Exércitos, esta fica ao lado de sua residência. A primeira tentativa para iniciar a Casa de Sementes foi durante o ano de 1994 a partir de uma roça comunitária, entretanto, o roçado não teve êxito e não foi possível iniciar as atividades pela ausência das sementes.

Porém no ano de 1998 o senhor Juvenal resolveu iniciar as atividades da Casa com as sementes oriundas do seu próprio roçado. De cada cultura que ele havia plantado no campo ele colheu uma pequena quantidade e armazenou. Durante a entrevista Seu Juvenal fez questão de ressaltar que foi no dia 18 de julho de 1998 em que a Casa foi inaugurada.

Após a implantação da Casa os agricultores fizeram mais duas tentativas com a roça comunitária, em 1998 e 1999, porém mais uma vez não conseguiram êxito. De acordo com o representante no dia do plantio muitos estavam presentes para contribuir, no entanto, no passar dos dias em que era necessário a manutenção da roça poucas pessoas apareciam.

Seu Juvenal explica que nessa época algumas Casas de Sementes estavam sendo implantadas no Nordeste e muitas eram denominadas como Banco, entretanto, o termo banco retoma a ideia "exploração, dinheiro” e por esse motivo os agricultores decidiram utilizar o termo Casa.

A escolha do nome para a Tecnologia Social também aconteceu durante esse período. Dois nomes foram sugeridos para votação, Casa de Sementes Senhor dos Exércitos e Casa de Sementes 
Germinação pra Valer, 46 pessoas estavam aptas a votar e 42 destas optaram pelo atual nome da Casa de Sementes.

No momento da entrevista o Senhor Juvenal deixou claro ser um homem religioso e de muita fé. O termo "Senhor dos Exércitos” está presente em muitas passagens bíblicas, a agricultor argumenta o porquê da escolha desse nome "Temos que se balizar nele, no Senhor dos Exércitos, aquele que criou o céu, a terra, o universo e é dono de tudo, da natureza".

A Casa possui um regimento interno desde o ano de 2002, este contém onze capítulos os quais descreve desde o objetivo da Tecnologia Social, os direitos e deveres do associado, os aspectos relacionados a gestão e outras regras e normas. O regimento completo está nos anexos desta dissertação.

Atualmente são 38 associados à Casa, segundo Seu Juvenal todo final de ano é realizado um levantamento da quantidade de sócios. Pois, caso um agricultor passe dois anos sem participar das reuniões e atividades da Casa ele não será mais sócio, apenas inscrito como também não poderá mais pedir empréstimos das sementes.

Para participar das atividades e ter direito aos empréstimos das sementes é necessário ser sócio, e para isso é preciso comprovar que é agricultor, preencher uma ficha cadastral e se comprometer a devolver o empréstimo acrescido quantidade estabelecida. Agricultores de outras localidades também podem associar-se à Casa, inclusive tem trabalhadores rurais de outras cidades.

Dois tipos de reuniões acontecem na Casa de Sementes, uma é com todos os associados e a outra é realizada com os membros da coordenação. A primeira é bimestral e acontece no primeiro sábado do mês às 14 horas; já a segunda ocorre a cada três meses no terceiro sábado do mês.

Quanto a gestão da Casa, seu Juvenal afirma que as eleições acontecem a cada quatro anos, no entanto, não existe interesse de mudança das pessoas que compõe a gestão pois, nenhum associado demonstra interesse. A coordenação é formada pelos cargos de primeiro coordenador, segundo coordenador, primeiro secretário, segundo secretário, primeiro tesoureiro, segundo tesoureiro e três conselheiros fiscais e seus respectivos suplentes.

Dentre as espécies disponíveis na Casa de Sementes: milho, feijão, arroz, andu, jerimum, melancia, quiabo, fava, abóbora e amendoim. Seu Juvenal mostra um levantamento realizado por ele que contêm a quantidade de variedades disponíveis na Casa. O milho e o feijão são as espécies mais emprestadas aos sócios.

Para o armazenamento da maioria das sementes é utilizada as garrafas PET, somente no caso do arroz e amendoim é utilizado sacos. Como na maior parte das Casas de Sementes visitadas os associados também têm o costume guardar sementes em casa.

São os próprios agricultores que realizam oficinas sobre as técnicas de coleta e armazenamento das sementes, esses momentos são compartilhados durante as reuniões que acontecem com frequência.

Conforme Seu Juvenal apesar das dificuldades, principalmente hídricas, as sementes disponíveis na Casa são suficientes para garantir o plantio de cada safra e para os empréstimos aos associados.

Alguns Intercâmbios de Sementes, realizados na região Norte do Estado do Ceará, em Recife e em Petrolina foram vivenciados por Seu Juvenal, que trocou sementes crioulas e experiências de campo com outros agricultores.

Apesar da Casa de Sementes Senhor dos Exércitos ser referência na região do Cariri como uma Tecnologia Social bem desenvolvida, está também passa por dificuldades, como o desinteresse de novas gerações e a falta de apoio e incentivo à Casa, destaca Seu Juvenal. 
Atualmente a Casa de Sementes não está sendo apoiada por nenhum projeto, no entanto, em 2006 um recurso de R\$ 3.150, 00 foi disponibilizado para a reconstrução da referida Casa, que até este ano era feita de taipa. O projeto foi realizado pela Cáritas Diocesana de Crato.

\subsection{CASA DE SEMENTES DA COMUNIDADE JENIPAPO}

As informações sobre a Tecnologia Social da comunidade Jenipapo, localizada no distrito Bela Vista, foram disponibilizadas pela agricultora Maria do Socorro Laurentino Cardoso de 46 anos.

A localidade tem aproximadamente 250 famílias, destas nem todas têm a agricultura como fonte de renda. Muitos trabalham no centro da cidade, alguns em escolas e hospitais.

De acordo com Maria do Socorro já existiu na comunidade Jenipapo uma Casa de Sementes, entretanto naquela época a agricultora não participava das atividades e por isso não soube informar os motivos que levaram a inativação. Atualmente, graças a iniciativas de alguns agricultores que fazem parte da Associação Comunitária da Comunidade iniciaram a reativação da Casa de Sementes.

Funcionando no mesmo prédio da Associação e ao lado da Casa de Farinha a Tecnologia Social foi intitulada temporariamente como Casa de Sementes da Associação Comunitária do Jenipapo. A representante argumenta que alguns agricultores estão ansiosos para o desenvolvimento das atividades da Casa, esta tem como objetivo disponibilizar sementes aos camponeses e desenvolver o trabalho em grupo.

Durante o diálogo a agricultora explicou que no momento as atividades e as reuniões da Casa de Sementes não estão ocorrendo com frequência pois, um dos sócios que tomava à frente dos interesses da Casa está passando por problemas particulares e teve que se ausentar das atividades do grupo. E é por esse motivo que muitas decisões a respeito da gestão da Tecnologia Social ainda não foram definidas, relatou a representante.

Dentre os aspectos que ainda não foram definidos a representante destaca o estatuto, as normas da Casa e o percentual de devolução das sementes que será determinado conforme a cultura que será emprestada. Além disso as eleições serão realizadas a cada dois anos, entretanto os cargos e funções necessários para a gestão da Tecnologia ainda não foram determinados.

O número de sócios da Casa ainda não foi estabelecido pois apenas alguns cadastros de agricultores interessados foram realizados. Porém, Dona Maria do Socorro ressalta que talvez este número seja aproximadamente 32 sócios já que os agricultores que demostram interesse em participar das atividades da Casa são os sócios da Associação Comunitária.

Os critérios para associar-se a Casa já foram estabelecidos: é necessário ser agricultor, preencher o cadastro e se comprometer a devolver a quantidade que pegou emprestado acrescida do percentual que será definido de acordo com a cultura.

Apesar de estar ativa, a Casa de Sementes da Comunidade Jenipapo, no momento da visita, não tinha sementes disponíveis para empréstimo. Contudo, segundo a representante, sementes de feijão, milho, fava e amendoim que são armazenados em garrafas PET, já compuseram o estoque da Casa.

As sementes necessárias para dar continuidade as atividades da Casa serão adquiridas através dos próprios agricultores, pois estes têm o costume de guardar sementes em suas residências. Além disso, Dona Maria do Socorro ressaltou que os agricultores propuseram pedir a contribuição de Organizações NãoGovernamentais que desenvolvem trabalhos nesse sentido. 
Entre as dificuldades apontadas pelos agricultores para reativar a Casa de Sementes foi destacado o desinteresse de novas gerações e a falta de incentivo. Mas de acordo com a representante esses obstáculos estão sendo superados pelos agricultores que cada vez mais demostram interesse em ir adiante com as atividades, como por exemplo o roçado comunitário que já está sendo organizado para potencializar a quantidade de sementes da Casa.

Apesar de não receber incentivos por parte de programas do Estado, a Comunidade conta com a ajuda dos próprios agricultores para o desenvolvimento da Tecnologia Social. O senhor Antônio de Assis, por exemplo, que mora na localidade vizinha, a Vila São Francisco, é um agricultor experiente que trabalhou por muitos anos com a semente crioula, ele participou de algumas reuniões na Comunidade Jenipapo no intuito de ajudá-los na reativação da Casa de Sementes.

\subsection{CASA DE SEMENTES CHICO DE AVELINA}

No dia 11/06/2016 a visita acorreu na Comunidade Chico Gomes, localizada no entorno da Floresta Nacional do Araripe e distante oito quilômetros da sede do município de Crato.

Participaram da entrevista Roseli dos Santos e o Manoel Leandro do Nascimento, dois jovens moradores e representantes da Comunidade, os quais disponibilizaram informações sobre a Tecnologia Social analisada.

A Comunidade Chico Gomes é composta por 47 famílias, destas a maioria pratica a agricultura. Os que não estão envolvidas com as atividades rurais e não são aposentados, trabalham em outros setores, como indústria, comércio, escolas, posto de saúde, e construção civil.
A Casa de Sementes Chico de Avelina foi intitulada com o nome de um agricultor falecido que residia na Comunidade como forma de homenageá-lo. Foi construída em 2010 a partir de um orçamento disponibilizado por um projeto desenvolvido pela Cáritas Diocesana.

Embora construída há seis anos a referida Tecnologia nunca esteve ativa. Conforme os representantes, a comunidade desejava ampliar o espaço da Casa de Sementes antes de iniciar as atividades, no entanto o tempo foi passando e a ampliação do espaço não aconteceu, além disso o cadastro dos agricultores que desejam associar-se à casa também não foi realizado.

Roseli e Manoel afirmaram que vários agricultores demostram interesse para a ativação da Casa de Sementes. Principalmente os trabalhadores rurais que ainda mantem o costume de guardar as sementes crioulas em suas residências, dentre as sementes guardadas por eles tem destaque o milho, feijão, jerimum e quiabo.

Entretanto apesar do costume dos bancos familiares ainda existir na Comunidade Chico Gomes, nota-se através do relato do Manoel Leandro que esta prática está ao longo dos anos entrando em decadência.

As Casas de Sementes elas são importantes também porque elas asseguram a diversidade. Por exemplo, aqui na nossa Comunidade existiam mais de 10 “espécies” de milho, hoje, se muito a gente tem dificuldade de encontrar 1 espécie só. Então, a Casa de Semente é importante para assegurar a diversidade das sementes que são plantadas nas comunidades

Provavelmente a falta de continuidade das sementes no campo e sua manutenção nos bancos familiares estão contribuindo para a perda da diversidade agrícola da Comunidade. Contudo, a preocupação e consciência da importância das Casas de Sementes é observada durante 
o relato do Manoel, que ressalta a conservação da agrobiodiversidade através da Tecnologia.

Próximo à Casa de Sementes é possível observar uma outra Tecnologia Social, a Mandala, que também não estava inativa no momento da visita. Os representantes justificaram que a Mandala está inativa pois os responsáveis em mantêla eram os jovens da Comunidade, entretanto muitos se ocuparam com outras atividades, principalmente na sede do município, e, portanto, dificultou a realização das atividades da Mandala.

Atualmente a Comunidade não está recebendo nenhum incentivo para a ativação da Casa de Sementes.

\subsection{CASA DE SEMENTES SANTA INÊS}

Construída pelos próprios agricultores, hoje a Casa de Sementes Santa Inês encontra-se inativa, sua estrutura localiza-se na Lagoa dos Faustinos, comunidade composta por 30 famílias e que faz parte do distrito Dom Quintino.

Segundo o agricultor e ex-sócio da Tecnologia Social, Antônio Parente Saldanha de 75 anos, ela mante-se ativa por aproximadamente dez anos. Porém, o agricultor não soube informar o ano de criação e extinção da Casa.

Durante a conversa com o senhor Antônio Parente ele ressaltou que apesar de todas as famílias do local dependerem da agricultura, nem todos eram associados à Casa quando esta era ativa. As reuniões aconteciam com frequência e eram realizadas simultaneamente com os encontros da associação; e os diálogos eram registrados em atas.

O percentual de devolução na Casa de Sementes Santa Inês era de 20\% em cima da quantidade total que foi emprestada.

No diálogo, o agricultor relembra sobre os bons tempos da Casa de Sementes, em que os associados tinham sementes à disposição quando necessitavam, eram independentes das sementes disponibilizadas pelo governo. No entanto, esse cenário mudou, atualmente os agricultores dependem dos insumos disponibilizados pelo governo.

Apesar da independência com as sementes e baixo percentual de devolução, o seu Antônio Parente argumenta que dois fatores influenciaram para a inativação da Casa: os agricultores começaram a demostrar desinteresse pelas atividades, bem como estavam faltando com a devolução das sementes. Ressalta ainda, que aqueles que devolviam não selecionavam as sementes, comprometendo o plantio seguinte.

Contudo, segundo o agricultor ainda é possível observar algumas manifestações de alguns agricultores para a reativação da Casa de Sementes, porém esse desejo ainda é tímido e não é compartilhado por todos.

Na comunidade Lagoa dos Faustinos o costume de guardar sementes nas residências não é compartilhado por todos os agricultores. Apesar disso, o milho, o feijão e a fava são as sementes armazenadas pelos poucos trabalhadores rurais que mantém essa tradição.

Atualmente a Comunidade não recebe nenhum incentivo para a ativação da Casa de Sementes.

\subsection{ASSENTAMENTO 10 DE ABRIL}

No dia 03/08/2016 a visita foi ao Assentamento 10 de Abril, lá conversei com a agricultora Luiza Eufrásio de Farias de 75 anos.

O Assentamento 10 de Abril está inserido no distrito de Monte Alverne, distante a $31 \mathrm{~km}$ da sede do município de Crato e é formado por 54 famílias agriculturas.

Dona Luiza inicia o diálogo relatando que a Casa de Sementes foi intitulada pelos agricultores como 
Armazém e manteve-se ativa por apenas 10 meses por volta do ano de 1996. Quando ativa, as reuniões aconteciam regularmente, porém, nem todos os agricultores da comunidade eram associados.

Apesar de pouco tempo ativa as atividades realizadas na Casa de Sementes nesse período foram satisfatórias, entre elas, a agricultora relata a roça comunitária desenvolvida pelos sócios da Casa. Fruto do trabalho em equipe os agricultores produziram arroz, milho e feijão. O arroz, especialmente, foi o que se destacou na produção.

Entretanto, a agricultora relatou que o desinteresse dos agricultores juntamente com a falta de chuva nos anos sucessores à 1996 contribuíram para a inativação da Casa de Sementes.

Hoje, apesar de muitos agricultores do Assentamento 10 de abril ainda manterem o costume de guardar sementes em casa, estas não são suficientes para suprir a necessidade de cada safra, e, portanto, são dependentes das sementes disponibilizadas pelo governo. Entre as sementes guardadas nos bancos familiares da comunidade, dona Luiza cita as principais que são o milho, feijão, fava, andu e o amendoim.

Durante a conversa estava presente a jovem Patrícia que é residente da comunidade, ela nos informou que atualmente a Associação e os jovens do Assentamento demostram interesse em reativar as atividades da Casa de Sementes.

\subsection{CASA DE SEMENTES PADRE CICERO}

A Vila São Francisco faz parte do distrito Ponta da Serra, distante da sede do Crato $10 \mathrm{~km}$ e possui aproximadamente 450 famílias. A maioria destas trabalham na sede do município e nas indústrias cerâmicas próximas à Vila, hoje, poucas famílias têm a agricultura como fonte de renda, de acordo com o senhor Antônio de Assis de 76 anos.
O Senhor Antônio relata que à Vila cresceu muito nos últimos anos pois, vinte e cinco anos atrás a comunidade tinha apenas 90 famílias. E nessa época a maioria das famílias eram agricultoras.

A Tecnologia Social que era intitulada como Casa de Sementes Padre Cicero funcionava em um quarto ao lado da residência do senhor Antônio. Este não soube informar com precisão o ano de criação e extinção da Casa de Semente, mas relata que foi entre os anos de 1997 e 1998 que foi criada e foi extinta entre 2003 e 2004.

Na época nem todos da comunidade eram sócios da Tecnologia Social, apenas 42 associados participavam das atividades da Casa e eles tinham como principal objetivo a independência quanto as sementes.

As reuniões aconteciam com frequência e os diálogos eram registrados em ata, quanto ao acréscimo do empréstimo das sementes era de $20 \%$, relembra Antonio de Assis.

No entanto, a principal causa da inativação da Casa de Sementes foi a falta de compromisso dos associados, pois eles pegavam uma quantia de sementes emprestadas e não pagavam o empréstimo. $E$ os agricultores que pagavam não selecionavam as sementes, foram esses fatos que desestimulou os agricultores e principalmente o Seu Antônio, que era o que se dedicava mais as atividades da Casa.

Hoje, poucos agricultores têm o costume de guardar as sementes em casa, e infelizmente os agricultores da comunidade não demostram interesse em reativar a Casa de Sementes, relata o representante.

\section{RELAÇÃO DIMENSÕES DA \\ SUSTENTABILIDADE E AS CASAS DE SEMENTES COMUNITÁRIAS}

Dentre os critérios da sustentabilidade proposto por Sachs, 
observamos que durante a realização desta pesquisa, através das entrevistas, depoimentos e observação do contexto é possível traçar uma relação entre as Casas de Sementes e quatro dimensões da sustentabilidade (a social, a cultural, a ambiental e a econômica).

\subsection{DIMENSÃO AMBIENTAL}

A conservação e manutenção das sementes, nas comunidades visitadas, através da Tecnologia Social estudada é uma das principais formas de preservação da agrobiodiversidade, a qual contribui para o alcance da sustentabilidade tendo como referência a dimensão ambiental.

Embora a maioria das Casas de Sementes visitadas estarem inativas durante a realização deste estudo, foi possível observar que todos os representantes das Comunidades reconhecem a importância dessa Tecnologia Social para a preservação da diversidade agrícola. Como ressalta o representante da comunidade Chico Gomes, Manoel Leandro:

[...] Por exemplo, aqui na nossa comunidade existiam mais de 10 especies de milho, hoje, se encontrar é duas. De arroz a gente também tinha várias, hoje a gente tem dificuldade de encontrar uma espécie só. Então, a casa de sementes é importante para assegurar a diversidade das sementes que são plantadas nas comunidades.

Na fala do senhor Manoel Leandro nota-se que ao mesmo tempo que ele argumenta a importância da Tecnologia, também expõe a sua preocupação com a erosão genética que vem ocorrendo em sua comunidade. Este fenômeno não é um fato isolado, pois de acordo com o Relatório sobre o Estado dos Recursos Genéticos de Plantas do Mundo realizado durante a $4^{\text {a }}$ Conferência Técnica Internacional sobre os Recursos Fitogenéticos, em 1996, na Alemanha, nos últimos cem anos os agricultores perderam entre 90 e 95\% de suas variedades agrícolas.

De acordo com o Relatório a principal causa da erosão genética é causada sobretudo pela substituição das variedades locais e tradicionais pelas variedades modernas que apresentam estreita base genética e alto rendimento.

Porém, com a proposta de resgatar, manter e conservar as variedades locais, as Casas de Sementes constituem uma importante proposta, especialmente para a agricultura familiar da região, para a preservação do patrimônio genético das comunidades.

Observa-se que ao mesmo tempo em que os agricultores são atingidos pelo processo da erosão genética, estes também são os principais protagonistas em manter as poucas variedades locais que ainda resistem. Conforme Santilli (2009) ao longo dos últimos $12 \mathrm{mil}$ anos os principais responsáveis pela enorme diversidade de plantas cultivadas e de agroecossistemas são os agricultores, através das práticas de manejo, cultivo e seleção de espécies.

Contribuindo para a discussão, em pelo menos três Tecnologias Sociais identificadas durante a pesquisa observamos a existência de uma ampla variedade de sementes. Na Casa de Sementes Senhor dos Exércitos, por exemplo, em seu último levantamento foi catalogado mais de 50 variedades, entre sementes de feijão, arroz, milho, fava, melancia e outras.

A importância da diversidade agrícola é a sua capacidade de se adaptar a condições adversas. Santilli (2009) argumenta que a diversidade resulta tanto de fatores naturais quanto de fatores culturais, e exemplifica: há sociedades que adaptam variedades de arroz ao cultivo aquático, submerso em água, em regiões úmidas; e há outras que adaptam variedades de arroz ao cultivo em regiões secas.

Os fatores naturais, ressaltados por Santilli (2009), podemos destacar o clima, o 
solo, relevo e a disponibilidade de água; e os fatores culturais, corresponde à transmissão de práticas e valores de geração em geração.

$\mathrm{Na}$ fala a seguir observamos a relação do homem com esse processo de adaptação das sementes:

E assim também é importante porque as sementes que são plantadas elas se adaptam ao ambiente, elas vão se adaptando, vão criando resistência de acordo com o lugar que ela está sendo plantada. Então, é importante também isso por a gente ficar com a semente com a característica do nosso lugar, do nosso ambiente [...]. (Manoel Leandro, Casa de Sementes Chico de Avelina da comunidade Chico Gomes.)

Durante esse processo de adaptação os agricultores observam o desenvolvimento das plantas através das suas características fenotípicas e genotípicas. Os aspectos fenotípicos são manifestados através da variação da cor, altura, formato das folhas etc. Já as variações genéticas são observadas através da resistência a pragas, doenças e a seca, por exemplo.

Diferentemente das variedades modernas as quais apresentam estreita base genética e alto rendimento, quando cultivadas de acordo com as condições ideais para o seu desenvolvimento, as variedades crioulas possuem uma ampla variabilidade genética o que contribui para a sua rusticidade e resistência em adaptar-se a ambientes extremos, diminuindo o risco de perdas dos plantios.

No relato do representante da Casa de Sementes Senhor dos Exércitos, Senhor Juvenal, que trabalha com as sementes tradicionais há muitos anos, ele deixa claro as vantagens do cultivo com as sementes crioulas:

E a nossa semente crioula ela tem várias diferenças, vários objetivos de bondade para o ser humano e para os animais também, porque, até o pasto da semente crioula é diferente dos transgênicos fica pequeno e pasto fraco, frágil. A semente crioula ela tem resistência com relação a praga, a lagarta, ao verão, enfim [...] a semente crioula é diferente da semente melhorada [...]

A rusticidade das sementes crioulas possibilita aos trabalhadores rurais produzir os alimentos sem a utilização de agrotóxicos:

A Casa de Sementes eu acho que seja um projeto importante para as comunidades. Para que as comunidades possam trabalhar com menos veneno [...]. (Dona Esmenia, Casa de Sementes Nossa Senhora da Conceição da comunidade Triunfo.)

Essa forma de cultivo, ambientalmente sustentável, contribui para a produção de alimentos sadios, livres de contaminação, contribuindo para a segurança alimentar e nutricional. De acordo com Fabre (2015) a agricultura familiar é a mais capaz de internalizar os sistemas de produção inspirados na agroecologia e na convivência com o semiárido, já que esses sistemas são mais ajustados às exigências do desenvolvimento sustentável.

Está claro que as Casas de Sementes e o cultivo das variedades crioulas contribuem, especialmente, para o desenvolvimento das comunidades as quais estão inseridas. Entretanto, durante as conversas foram destacadas algumas limitações enfrentadas pelos sócios das Casas de Semente. Entre elas, o desinteresse dos jovens (pouca mão de obra), a falta de apoio e incentivo, e as condições climáticas.

Em relação as condições climáticas, os agricultores se referiam a falta de chuva na região nesses últimos anos.

Corroborando com os agricultores, em um levantamento realizado pelo meteorologista David Ferran, da Fundação 
Cearense de Meteorologia e Recursos Hídricos (FUNCEME), no Estado do Ceará, entre os anos de 1910 e 2016 apresenta duas ocasiões com cinco anos de Seca, a primeira foi de 1979 a 1983, com média de $566 \mathrm{~mm}$; e a segunda, de 2012 a 2016, com média de $516 \mathrm{~mm}$. Ou seja, de acordo com o estudo o Ceará está passando pela seca mais intensa desde 1910 (FUNCEME, 2016).

Conforme o IPECE, o período chuvoso na região de estudo da pesquisa se concentra entre os meses de janeiro a maio.

Durante o período chuvoso a região sul do estado do Ceará manteve-se classificado desde Seca Grave à Seca Excepcional. De acordo com a tabela de classificação de severidade da Seca os possíveis impactos com essa classificação é a perda de culturas e pastagens, bem como a escassez de água nos reservatórios, córregos etc. que poderá criar emergências.

Destacando a agricultura, um dos setores impactados pela seca prolongada, é comum em diversas regiões do país, como no Ceará e especialmente na região de estudo desta pesquisa, o desenvolvimento da agricultura de sequeiro. Esta é uma técnica de cultivo em que as culturas são semeadas durante o período chuvoso, portanto, existe variações oscilantes na produção e, consequentemente, na produtividade, dependendo das condições climáticas de cada ano. afirmam:

Fernandes e Maciel, 2010,

No Ceará, onde o semiárido abrange 86,8\% da área do estado, estão inseridos 150 municípios de um total de 184. Nessa área, a agricultura de sequeiro, representa uma parcela significativa da atividade econômica e está constantemente, sujeita a irregularidades na distribuição das chuvas (veranicos), capazes de provocar grandes desequilíbrios na produção agrícola local.

Podemos afirmar, a partir das conversas com os agricultores e dos estudos acima citados, que a escassez de chuva tem influenciado na produção agrícola nos últimos anos, principalmente na produção dos agricultores familiares, que utilizam o sistema de sequeiro em suas propriedades.

Entretanto, apesar desses impasses, pelo menos três Casas de Sementes ativas da região de estudo manteve o estoque de sementes. Embora não em grande quantidade, mas o suficiente para manter as variedades existentes na Tecnologia.

Portanto, a sustentabilidade ambiental, é alcançada através do uso das sementes crioulas que mesmo diante de períodos de seca mantém a produção. Além disso, a Tecnologia Social que mantém as sementes tradicionais contribui para a autonomia dos sócios-agricultores da região.

\subsection{DIMENSÃO ECONÔMICA}

Na perspectiva econômica as Casas de Sementes contribuem para a autonomia dos agricultores, a segurança alimentar e o desenvolvimento local, esses atributos foram destacados pelos entrevistados e observados durante a pesquisa.

Fabre (2015) ressalta que dentro dos atributos do conceito de sustentabilidade, aplicada ao desenvolvimento rural, entende-se que os princípios de autonomia e resiliência, em relação ao sistema de produção agropecuário, também merece destaque.

De acordo com autor a autonomia considera o acesso aos fatores de produção (terra, água, sementes, força de trabalho, tecnologias etc.), os processos de organização, de tomada de decisão e a capacidade do sistema para definir internamente suas próprias estratégias de reprodução econômica e técnica, seus objetivos, suas prioridades, sua identidade e seus valores.

Dona Antoneide, representante da Casa de Sementes do Sítio Várzea Furtos da Vida, argumenta: 
Ô a importância pra nós, assim, da Casa de Sementes é por conta de a gente ter uma semente selecionada, né! Uma coisa mais escolhida que não vai depender só do governo, só vai depender da comunidade para que escolha sua semente, que tenha a semente na hora certa para plantar, né! Para quando chegar o momento certo já está com a semente ali [...].

Percebe-se na fala da agricultura, que especialmente o acesso às sementes na hora desejada pelo trabalhador rural é uma das principais contribuições das Casas de Sementes. Pois, muitas vezes o agricultor que não tem acesso a essa Tecnologia Social depende da distribuição das sementes por parte dos órgãos estaduais.

No estado do Ceará, por exemplo, as sementes são distribuídas pela EMATERCE através do Programa Hora de Plantar. Porém, de acordo com os agricultores as sementes não são distribuídas no momento certo, muitas vezes o órgão distribui o insumo após as melhores chuvas já terem ocorrido.

Além disso, os entrevistados argumentaram um outro motivo, negativo, em esperar as sementes distribuídas pelo Estado. Segundo eles no primeiro ano do plantio com as sementes distribuídas a produção é até significativa, porém, no segundo, a produção é pouco expressiva.

[...] E a semente crioula é diferente[...] você planta esse ano e no próximo ano não pode plantar da mesma, e aí fica sujeito ao governo com relação a semente. (Seu Juvenal, Casa de Sementes Senhor dos Exércitos.)

A este fato podemos explicar, pois, uma parte das sementes distribuídas pelo Programa Hora de Plantar é semente híbrida.

Híbrido pode ser definido como a primeira geração proveniente do cruzamento entre variedades de polinização aberta, linhagens endogâmicas ou outras populações geneticamente divergentes; a principal vantagem do híbrido é a heterose, ou seja, a manifestação das melhores características e consequentemente maior produtividade. Entretanto, a heterose é reduzida em torno de $48 \%$, caso ocorra o plantio das sementes colhidas de um híbrido - segunda geração (ALLARD, 1971; COELHO e VIANA, 1980).

Assim, os agricultores têm razão, pois a produtividade não é alcançada com o plantio das sementes de um híbrido, sendo necessário, portanto, obter todos os anos as sementes que são distribuídas pelo Programa.

Porém, com o processo de organização e a capacidade de definirem suas próprias estratégias, os agricultores sócios das Casas de Sementes visitadas, não precisam esperar a distribuição das sementes para iniciarem o plantio, nem mesmo ficar sujeito a perdas na produção, já que na Tecnologia Social é mantida as sementes tradicionais que são adaptadas as condições locais.

Embora na pesquisa apenas duas Casas de Sementes apresentaram variedades em quantidades suficientes para atender seus sócios, podemos afirmar que as estratégias de manutenção de estoques garantem a autonomia dos agricultores em relação a este insumo, possibilitando maior desenvolvimento econômico familiar e local.

De acordo com Queiroga et al. (2011) o funcionamento do Banco de Semente é semelhante com um banco comum, porém a moeda de troca é a semente. O intuito é que o banco seja fortalecido, então a quantidade a ser devolvida terá que ser superior à emprestada. Durante a pesquisa, em pelo menos duas Casas de Sementes visitadas a quantidade a ser devolvida pelo sócio deve ser acrescida em $100 \%$.

Fomentado a economia local, os produtos, oriundos dos plantios de alguns agricultores sócios das Casas de Sementes, 
são comercializados na própria Comunidade ou em feiras da cidade.

Além da comercialização, esses produtos também contribuem para a alimentação familiar dos agricultores envolvidos com a Tecnologia. Portanto, considerando a forma e o contexto como são produzidos (agroecológico) contribuem para a segurança alimentar.

A Lei 11.346 que institui o Sistema Nacional de Segurança Alimentar e Nutricional, conceitua:

\section{A Segurança Alimentar e Nutricional consiste na realização do direito de todos ao acesso regular e permanente a alimentos de qualidade, em quantidade suficiente, sem comprometer o acesso a outras necessidades essenciais, tendo como base práticas alimentares promotoras de saúde que respeitem a diversidade cultural e que sejam ambiental, cultural, econômica e socialmente sustentáveis”}

Durante a pesquisa foi possível observar que os agricultores compartilham de atitudes agroecológicas, ou pelo menos estão no processo de transição. Além disso, nas Casas de Sementes são mantidos diversos tipos de semente. Ou seja, a conservação da agrobiodiversidade associada à produção sustentável de alimentos contribui para a promoção da qualidade dos alimentos consumidos e comercializados pelos sócios da Casas de Sementes.

No relato a seguir, o senhor Francieudo se preocupa em manter as sementes crioulas para garantir uma a alimentação de qualidade para as futuras gerações:

[...] que não se perca essas sementes porque quando a gente ta guardando com certeza vai ter a expectativa que lá na frente nossos filhos vão ter uma semente de qualidade e garantir alimentação saudável pra eles. (Fracieudo Elias da Silva, Casa de Sementes L.S.A da Serra do Catolé.)

Sendo assim podemos reconhecer que as Casas de Sementes visitadas, embora nem todas estarem em seu pleno funcionamento, corroboram para o desenvolvimento econômico local garantindo aos que consomem os produtos oriundos desta uma alimentação de qualidade.

\subsection{DIMENSÃO SOCIOCULTURAL}

Para Chacon (2007) na dimensão sociocultural 0 processo de desenvolvimento está relacionado com os seres em sociedade e suas relações; saber como as pessoas vivem e seus valores culturais devem ser conhecidos e considerados.

Durante as visitas, a percepção da sustentabilidade através de indicadores das dimensões social e cultural também foram evidentes. Palavras-chaves, como antepassados e coletividade foram relatadas pela maioria dos participantes desta pesquisa.

Entre os entrevistados, os representantes das Casas de Sementes Senhor dos Exércitos (Sr. Juvenal), Santa Inês (Sr. Antônio Parente), Padre Cicero (Sr. Antônio de Assis) e do Assentamento 10 de abril (Sra. Angelina) eram os que tinham mais idade. Na conversa, o máximo de atenção, pois eles carregam em suas memórias as lembranças mais antigas sobre as sementes e o processo de organização das comunidades os quais estão inseridos

Apesar das visitas não durarem muito tempo, as informações compartilhadas pelos representantes nos ajudaram a entender e valorizar ainda mais os conhecimentos e saberes populares.

Silva e Neto (2015) argumentam sobre o saber popular:

[..] acúmulo de saberes intuitivos ou conhecimentos práticos, desenvolvidos pelos próprios humanos, que tornam possível sua 
existência até os dias de hoje. Nessa caminhada da humanidade, foi ocorrendo um processo seletivo de saberes, desde o começo da relação entre o homem e a natureza, que se reproduziram e vêm sendo repassados para as novas gerações

Nas comunidades visitadas, algumas tradições e saberes populares são mantidos e fortalecem a identidade do lugar, entre esses costumes, os agricultores familiares ainda conservam as sementes crioulas que eram dos seus ancestrais. sentimento:

O senhor Juvenal compartilha desse

[...]E a semente crioula é por ser uma semente dos nossos ancestrais, a semente que realmente a gente pode plantar, pode confiar que ela reproduz quantas vezes você tentar a reprodução dela.

Na Comunidade Catolé, em Nova Olinda, o Francieudo ressalta a importância em manter as sementes através da Tecnologia Social que está para ser inaugurada em sua comunidade:

Eu acho que a importância da Casa é que o agricultor ter a sua própria semente e manter e não perder também porque já vem de nossos antepassados e eu acho que garantir para as futuras gerações que não se perca essas sementes [...]

Compreende-se que as Casas de Sementes proporcionam aos associados a manutenção da dinâmica cultural da localidade. Uma vez que a preservação da agrobiodiversidade, bem como o saber popular são mantidos e valorizados por essa Tecnologia.

Além disso, a dinâmica social das comunidades também é fortalecida. Chacon (2007) relata que os aspectos da organização local são fundamentais para o sucesso de qualquer iniciativa que vise $o$ desenvolvimento sustentável.
Há quase 20 anos a Casa de Sementes Senhor dos Exércitos é exemplo para as futuras Tecnologias que estão iniciando suas atividades. Pois, apesar de estar localizada próximo à cidade, seus sócios e defensores não permitiram que essa aproximação os desligasse das atividades do meio rural e de manterem as sementes tradicionais.

Seu Juvenal ressalta que os associados devem permanecer organizados e compartilhar de um objetivo em comum:

[...] a casa de sementes é no sentido de organizar, de reeducar as pessoas, está organizado em torno de uma função coletiva.

$\mathrm{Na}$ Comunidade Chico Gomes, embora não tenha iniciado as atividades da Casa de Sementes, o trabalho em grupo também é visualizado entre as vantagens da Tecnologia, relata o representante da localidade:

[...] aqui as pessoas já têm esse costume de guardar, embora, eles já tenham, mas a gente imagina que através da Casa de Sementes além dessa cultura de guardar a semente a gente incentiva a cultura do coletivismo, da coletividade, do trabalho em grupo. É bem complicado isso, mas eu acho que é muito importante. Ai a semente é esse elemento que pode aglutinar as pessoas. (Manoel Leandro.)

Além de contribuírem para a união e o trabalho em equipe, as Casas de Sementes também proporcionam a socialização entre as Comunidades, através dos intercâmbios. Dona Antoneide, da Comunidade Várzea em Nova Olinda, demostra a expectativa dos agricultores da localidade em iniciar as atividades e os intercâmbios:

[...] E a gente como está iniciando, a gente está na expectativa de arrumar mais sementes, nos intercâmbios pra fique na comunidade, que a gente possa visitar outras comunidades e fazer o intercâmbio de sementes e trazer 
lá juntamente com a Casa de Sementes. (Dona Antoneide)

As trocas que ocorrem nesses encontros contribuem para difundir as variedades de sementes e os saberes populares da nossa região.

\section{CONCLUSÕES}

No município de Crato-Ce foram identificadas sete Casas de Sementes Comunitárias, dessas três ativas e quatro inativas.

A falta de incentivo e apoio, o desinteresse dos jovens e as condições climáticas são os principais motivos que influenciam a inativação das Casas de Sementes identificadas na pesquisa.

Apesar de existir algumas ações e iniciativas que apoiem e fortaleçam as Casas de Sementes na região, essas ocorrem de forma isolada e descontínua.

Entre as contribuições das Casas de Sementes Comunitárias para o desenvolvimento sustentável foram observadas à preservação da agrobiodiversidade, a autonomia dos agricultores, a segurança alimentar, o coletivismo, a valorização dos conhecimentos e saberes populares e o desenvolvimento econômico das comunidades.

\section{AGRADECIMENTOS}

Universidade Federal do Cariri, CNPq e Funcap.

\section{REFERÊNCIAS}

ALLARD, R.W. Princípios do melhoramento genético das plantas. São Paulo: Edgard Blücher, 1971. 381p.

ALTIERI, M. Agroecologia: bases científicas para uma agricultura sustentável. Guaíba: Editora
Agropecuária; Rio de Janeiro: AS-PTA, 2002. 592 p.

ALTIERI, M.; NICHOLLS, C. Sementes nativas: patrimônio da humanidade essencial para a integridade cultural e ecológica da agricultura camponesa. In CARVALHO, H.M. (Org.). Sementes: patrimônio do povo a serviço da humanidade. São Paulo: Expressão Popular, 2003. pp. 159-172. Disponível em:

http://www.reformaagrariaemdados.org.br/ sites/default/files/Sementes\%20-

\%20Patrim\%C3\%B4nio\%20do\%20povo\% 20a\%20servi\%C3\%A7o\%20da\%20humani dade\%20-

\%20Horacio\%20Martins\%20de\%20Carval ho\%20\%28org.\%29\%20-

\%20Express\%C3\%A30\%20Popular,\%202 003.pdf. Acesso em: 22 jan. 2016.

ANA - ARTICULAÇÃO NACIONAL DE AGROECOLOGIA. Oficina sobre Sementes Crioulas e Políticas Públicas. 2012. Disponível em:< http://aspta.org.br/wpcontent/uploads/2012/10/Relato-OficinaANA-Sementes-BSB-set20121.pdf>.

APPOLINARIO, F; Metodologia da ciência: filosofia e prática da pesquisa. São Paulo: Cengage Learning, 2006.

ASSUNÇÃO, G. P; SEVERINO, M. R. Análise dos relatos de tecnologias sociais implementadas no Estado de Goiás para o desenvolvimento do empreendedorismo social. XXXV ENCONTRO NACIONAL DE ENGENHARIA DE PRODUCAO Perspectivas Globais para a Engenharia de Produção Fortaleza, CE, Brasil, 13 a 16 de outubro de 2015. Disponível em:< http://www.abepro.org.br/biblioteca/TN_S TO_213_262_27404.pdf $>$. Acesso em: 12 jan. 2016.

BEVILAQUA, G; ANTUNES, I. F; BARBIERI, R. L; SILVA, S. D. A. 
Desenvolvimento in situ de cultivares crioulas através de agricultores Guardiões de Sementes. Revista Brasileira de Agroecologia, v. 4, n.1, 2009.

BARDIN, L. Análise de Conteúdo. Lisboa: Edições 70, 1977.

CARVALHO, T. R. A; LUCENA, R. G; RANGEL, R. R; BRITO, M. C; FREITAS JÚNIOR, S. P. Quantificação das Casas de Sementes da Região do Cariri Cearense. IV ENCONTRO UNIVERSITÁRIO DA UFC NO CARIRI, JUAZEIRO DO NORTE, 2014.

Disponível em

$<$ https://www.google.com.br/url?sa=t\&rct $=\mathrm{j} \& \mathrm{q}=\&$ esrc $=\mathrm{s} \&$ source $=$ web $\& \mathrm{~cd}=1 \& \mathrm{cad}=$ rja\&uact $=8 \&$ ved $=0$ ahUKEwjPv_bfpsvUA hVCkZAKHYhnBHkQFggjMAA\&url=htt ps\%3A\%2F\%2Fencontros.ufca.edu.br\%2F index.php $\% 2$ Fencontrosuniversitarios $\% 2$ Feu2012\%2Fpaper\%2Fdownload\%2F1164\%2 F850\&usg=AFQjCNFIYChMFHQ2T8OA oah2W2wTfq2ksA\&sig2=KfS5zaaH4gp3Qq2SIaAsg>. Acesso em: 10 nov. 2016.

CHACON, S. S. O sertanejo e o caminho das águas: políticas públicas, modernidade e sustentabilidade no semiárido. Fortaleza: Banco do Nordeste do Brasil, 2007. 354p.

CONAB - COMPANHIA NACIONAL DO ABASTECIMENTO.

Acompanhamento da safra brasileira de grãos, v. 2, n. 3. Brasília, 2014. Disponível em

http://www.conab.gov.br/OlalaCMS/uploa ds/arquivos/15_01_09_09_00_21_boletim _graos_janeiro_2015.pdf $>$. Acesso em: 18 jun. 2015.

DAGNINO, R. TECNOLOGIA SOCIAL: Ferramenta para construir outra sociedade. Campinas: Unicamp, 2009. 95 p.
EMPERAIRE, L. O que é domesticação. In: Instituto Socioambiental. Almanaque Brasil Socioambiental: uma nova perspectiva para entender o país e melhorar nossa qualidade de vida. São Paulo, 2004.

EMPRESA DE ASSISTÊNCIA TÉCNICA E EXTENSÃO RURAL DO CEARÁ EMATERCE et al. Quintais produtivos. Ceará, 2009.

FABRE, Nicolas Arnaud. Convivência com o semiárido: produção. Fortaleza: Fundação Demócrito Rocha, 2015. 52 p.

FERNANDES, R.M.C; MACIEL, A.L.S. Tecnologias sociais: experiências e contribuições para o desenvolvimento social e sustentável. 2010, 44p.

FUNCEME. Fundação Cearense de Meteorologia e Recursos Hídricos Compartimentação Geoambiental do Estado do Ceará. Fortaleza-CE. 2009.

GARNINDO, L. O Cultivo de sementes crioulas no sudeste Goiano: uma forma da (Re)existência camponesa no campo. In: XIX Encontro Nacional de Geografia Agrária, São Paulo, 2009. Disponível em http://www.geografia.fflch.usp.br/inferior/l aboratorios/agraria/Anais\%20XIXENGA/a rtigos/Garcindo_L.pdf. Acesso em: 19 nov. 2015.

GREENPEACE. Transgênicos: a verdade por trás do mito. Cartilha elaborada pela Campanha de Engenharia Genética do Greenpeace. S.n.t. Disponível em:

$<$ http://www.greenpeace.org.br/transgenico s/pdf/cartilha.pdf $>$. Acesso em:18 jun. 2015.

INSTITUTO DE TECNOLOGIA SOCIAL. Conhecimento e Cidadania 1: Tecnologia Social (2007). Disponível em http://www.itsbrasil.org.br/sites/itsbrasil.w 20.com.br/files/Digite_o_texto/Caderno_S 
erie_Conhecimento_e_Cidadania__Tecnologia_social_-_1.pdf

INSTITUTO DE PESQUISA E ESTRATÉGIA ECONÔMICA DO CEARÁ (IPECE). Perfil Básico Municipal de Crato, 2015. Disponível em $<$

http://www.ipece.ce.gov.br/perfil_basico_ municipal/2015/Crato.pdf>

JESUS, V. M. B; COSTA, A. B. Tecnologia Social e Políticas Públicas. Adriano Borges Costa (Org). São Paulo: Instituto Pólis; Brasília: Fundação Banco do Brasil, 2013. 284p.

LACEY, H. As sementes e o conhecimento que elas incorporam. São Paulo em Perspectiva, v. 14, n. 3, p. 53-59. jul/set 2000.

LAMARCHE, H. A agricultura familiar. v. 5. São Paulo: UNICAMP, 2007.

LIMA, A. E. F.; SAMPAIO, J. L.

F. Sementes crioulas e autonomia camponesa: a experiência de soberania alimentar na comunidade de mombaba de baixo - Massapê - Ceará - Brasil. Disponível em: <

https://www.google.com.br/search?q=Sem entes+crioulas+e+autonomia+camponesa: $+\mathrm{a}+$ experi\%C3\%AAncia+de+soberania+al imentar+na+comunidade+de+mombaba $+d$ e+baixo+\%E2\%80\%93+Massap\%C3\%AA +\%E2\%80\%93+Cear\%C3\%A1+\%E2\%80 $\% 93+$ Brasil\&ie $=$ utf-8\&oe $=$ utf-

8\&gws_rd=cr\&ei=Od-

jVqOCDYW9wAT9_ajYBw >. Acesso em: 04 dez. 2015.

LONDRES, F. Sementes da diversidade: a identidade e o futuro da agricultura familiar. Agriculturas, v.11, n.1, 2014.

MACHADO, A. T. Construção histórica do melhoramento genético de plantas: do convencional ao participativo. Revista
Brasileira de Agroecologia, v. 9, n. 1, 2014.

MACHADO, L.C.P.; MACHADO FILHO, L.C.P.; RIBAS, C.D.E.C. Sementes, Direito Natural dos Povos. In: CARVALHO, H. M. (Org.). Sementes: patrimônio do povo a serviço da humanidade. São Paulo: Expressão Popular, 2003. pp. 245- 258. Disponível em: $<$

http://www.reformaagrariaemdados.org.br/ sites/default/files/Sementes\%20-

\%20Patrim\%C3\%B4nio\%20do\%20povo\% 20a\%20servi\%C3\%A7o\%20da\%20humani dade\%20-

\%20Horacio\%20Martins\%20de\%20Carval ho\%20\%28org.\%29\%20-

\%20Express\%C3\%A3o\%20Popular,\%202 003.pdf>. Acesso em: 22 jan. 2016.

MARCONI, M. A; LAKATOS, E. M. Técnicas de pesquisa: planejamento e execução de pesquisas, amostragens e técnicas de pesquisas, elaboração, análise e interpretação de dados. 6 ed. São Paulo: Atlas, 2007.

MAZOYER, M; ROUDART, L. 1933. História das agriculturas no mundo: do neolítico à crise contemporânea. São Paulo: Editora UNESP. 2010.

MDA - MINISTÉRIO DO

DESENVOLVIMENTO AGRÁRIO.

Biodiversidade: passado, presente $\mathrm{e}$ futuro da humanidade. 2006. Disponível em: <

http://www.centroecologico.org.br/cartilha s/cartilha_agrobiodiversidade.pdf $>$.

Acesso em: 14 jan. 2016.

NOVAES, H. T; DIAS, R. TECNOLOGIA SOCIAL: Ferramenta para construir outra sociedade. Renato Dagnino (Org). Campinas: Unicamp, 2009. 95 p.

PETERSEN, P; SILVEIRA, L; DIAS, E; CURADO, F; SANTOS, A. Sementes ou grãos? Lutas para desconstrução de uma 
falsa dicotomia. Revista Agriculturas: experiências em agroecologia, v.10, n.1. Rio de Janeiro: AS-PTA, julho de 2013. Pp 36-46.

QUEIROGA, V.P; SILVA, O.R.F; ALMEIDA, F.A.C. Tecnologias para o desenvolvimento da agricultura familiar : Bancos Comunitários de Sementes. Campina Grande: Fraternidade de São Francisco de Assis. Universidade Federal de Campina Grande, 1 ed.,2011.

Disponível em

<http://www.deag.ufcg.edu.br/rbpa/sement es.pdf > . Acesso em: 05 nov. 2015.

REIS, M.R. Tecnologia Social de Produção de Sementes e Agrobiodiversidade. Dissertação de Mestrado-Centro de Desenvolvimento Sustentável da Universidade de Brasília. Brasília: UNB, 2012. 288 p.

SACHS, I. Caminhos para o desenvolvimento sustentável. (Coleção Idéias Sustentáveis). Rio de Janeiro: Garamond, 2009.

SANTILLI, J. A Lei de Sementes brasileira e os seus impactos sobre a agrobiodiversidade e os sistemas agrícolas locais e tradicionais. Boletim do Museu Paraense Emílio Goeldi. Ciências Humanas, v. 7, n. 2, p.457-475, maio-ago. 2012.

SANTILLI, J. Agrobiodiversidade e direito dos agricultores. São Paulo: Peirópolis, 1 ed., 2009.

SERENO, M. J. C. M; WIETHOLTER, P; TERRA, T. F. Domesticação das plantas. In: Origem e evolução de plantas cultivadas. Brasília, DF: Embrapa Informação Tecnológica, 2008, p. 56. Disponível em:

$<$ https://www.google.com.br/search?q=Ori gem + e+evolu\%C3\%A7\%C3\%A3o+de+pla ntas+cultivadas.+Bras\%C3\%ADlia,+DF:+ Embrapa+Informa\%C3\%A7\%C3\%A3o+T
ecnol\%C3\%B3gica,+2008\&ie=utf$8 \&$ oe $=$ utf8\&gws_rd $=$ cr\&ei $=25 \mathrm{~K} 0$ VriWDcSuwASY 6r7IBA>. Acesso em: 14 jan. 2016.

SILVA DE ALENCAR-LINARD , Z.U.; SAEED-KHAN, A.; LIMA, P. V.P. S. Percepções dos impactos ambientais da indústria de cerâmica no município de Carto estado do Ceará, Brasil. Economía, Sociedad y Territorio, vol. xv, núm. 48, 397-423, 2015.

WANDERLEY, M. N. B. Raízes históricas do campesinato brasileiro. In: TEDESCO, João Carlos. Agricultura Familiar: realidades e perspectivas. $3^{\circ} \mathrm{ed}$. Passo Fundo: Ed. UFP, 2001. p. 21 - 56. 